\title{
DEVELOPMENT OF PIG EMBRYOS FOLLOWING RESTRICTION TO THE AMPULLAR PORTION OF THE OVIDUCT*
}

\author{
C. E. POPE AND B. N. DAY \\ Missouri Agricultural Experiment Station, \\ Department of Animal Husbandry, Columbia 65201, U.S.A.
}

(Received 7th March 1972, accepted 1st May 1972)

In most mammalian species, development to the blastocyst stage is reached after the embryo passes from the oviduct into the uterus. Blastocyst formation has also been observed in fertilized ova retained in the oviduct of the mouse (Kirby, 1962; Orsini \& McLaren, 1967), rat (Alden, 1942) and rabbit (Adams, 1958) following the placing of a ligature at the uterotubal junction. Early mouse (Whitten, 1956; Brinster, 1963; Whitten \& Biggers, 1968), rabbit (Kane \& Foote, 1970) and rat (Folstad, Bennett \& Dorfman, 1969) embryos have even been cultured to the blastocyst stage in vitro in a chemically defined medium. Billington, Graham \& McLaren (1968) reported that tubal mouse embryos cultured in vitro to the blastocyst stage and transferred to an ectopic site were capable of forming well-differentiated embryos.

According to Krishnan \& Daniel (1967), a specific uterine secretion termed blastokinin stimulates blastocyst formation in the late rabbit morula during culture in vitro in a chemically defined medium. Murray, Bazer, Rundell, Vincent, Wallace \& Warnick (1971) reported that blastulation did not occur in pig embryos retained in the oviduct following the placing of a ligature at the uterotubal junction. They suggested that pig embryos must reach the uterine environment before blastulation can occur and experiments were initiated to determine if the uterine secretions of the pig contain blastokinin-like factor(s) that are necessary for blastocyst development.

Since Whittingham (1968) was able to obtain blastocyst formation when fertilized one-cell mouse eggs were cultured in the explanted ampullar, but not isthmic, portion of the mouse oviduct, the present study was conducted to determine the degree of development which pig embryos would undergo when restricted to the ampullar portion of the oviduct.

A total of ten crossbred gilts varying from 8 to 12 months of age was used. Four of the gilts were injected with 1500 i.u. PMSG on the 15th day of the oestrous cycle. The first day on which oestrus was observed was designated Day 0 . The gilts were artificially inseminated on each day of oestrus. On Day 2, a midventral laparotomy was performed and a ligature was placed at the junction of the ampullar and isthmic portions of the oviduct. A second laparotomy was performed 3, 4, 5 or 6 days later in order to recover embryos restricted to the

\footnotetext{
* Contribution from the Missouri Agricultural Experiment Station. Journal Series Number 6325.
} 
ampullar region of the oviduct as well as uterine embryos from the contralateral uterine horn. Embryos were recovered by flushing the ampulla or the uterine horn with a sterile solution of normal saline or a supplemented KrebsRinger balanced salt solution. After recovery, the embryos were observed with a stereomicroscope to ascertain their stage of development, i.e. cleavage stage, blastocyst formation, enlargement and presence or absence of the zona pellucida. The diameter of embryos from three gilts was determined at recovery by the use of an eyepiece micrometer. The embryos were then fixed in acetic alcohol and stained in $1 \%$ aceto-orcein for further examination.

The results are shown in Table 1. Eleven of the eggs recovered from the ampulla of one gilt on Day 5 had an average of 36 (30 to 45) cells with five of the embryos having progressed to the early blastocyst stage. The twenty-one uterine embryos recovered from this gilt had an average of 45 (30 to 58) cells. Five of these embryos were early blastocysts. In a second gilt in which ovulation was induced with HCG, the average cleavage stage $127 \mathrm{hr}$ after HCG treatment was 16 ( 6 to 32 ) and 17 (2 to 32 ) cells for ampullar and uterine eggs, respectively.

By Day 6 of pregnancy, embryos retained in the ampulla were developing at a slower rate than the uterine embryos in most gilts. In one gilt, however, two blastocysts of 28 and 42 cells, respectively, were recovered from the ampulla, one early blastocyst ( 28 cells) and two morulae ( 22 and 26 cells) were removed from the uterus on the ligated side, and two blastocysts (30 cells) and two morulae (22 and 26 cells) were flushed from the contralateral uterine horn.

Although the development of embryos in the ampulla was retarded by the time of recovery from most gilts, the stage of development of ampullar and uterine embryos between gilts generally remained proportional as the interval from fertilization increased. For example, uterine blastocysts with zonae recovered from one gilt on Day 6 had an average of 62 cells compared with an average of 32 cells in the ampullar embryos. In another gilt on Day 6, the uterine embryos had reached an average cell stage of 188, were expanding $(0.257 \mathrm{~mm}$ average diameter) and had lost their zonae, while the ampullar blastocysts still retained their zonae and had an average of 68 cells per embryo. A third gilt on Day 6 yielded expanding uterine blastocysts of several hundred cells per embryo, and the slightly expanded ampullar blastocysts which had lost their zonae, had about 100 to 125 cells per embryo.

On Day 7 after the onset of oestrus in three gilts, blastocysts were recovered from the ampullae of two of them and the third gilt had embryos at the morula stage with approximately 40 to 80 cells per embryo. Three of four ampullar embryos from one of the gilts were blastocysts that had an average of 121 cells and an average diameter of $0.186 \mathrm{~mm}$ while an enlarging uterine blastocyst had a diameter of $0.225 \mathrm{~mm}$, including the zona, and consisted of 129 cells. Uterine embryos from the other two gilts were expanding blastocysts which had lost their zonae and consisted of several hundred cells.

The results of this experiment in which pig embryos restricted to the ampullar region of the oviduct were found to be fully capable of blastocyst formation agree with the results of experiments in which tube-locked embryos of other species were studied both in vivo (Alden, 1942; Adams, 1958; Kirby, 1962; 


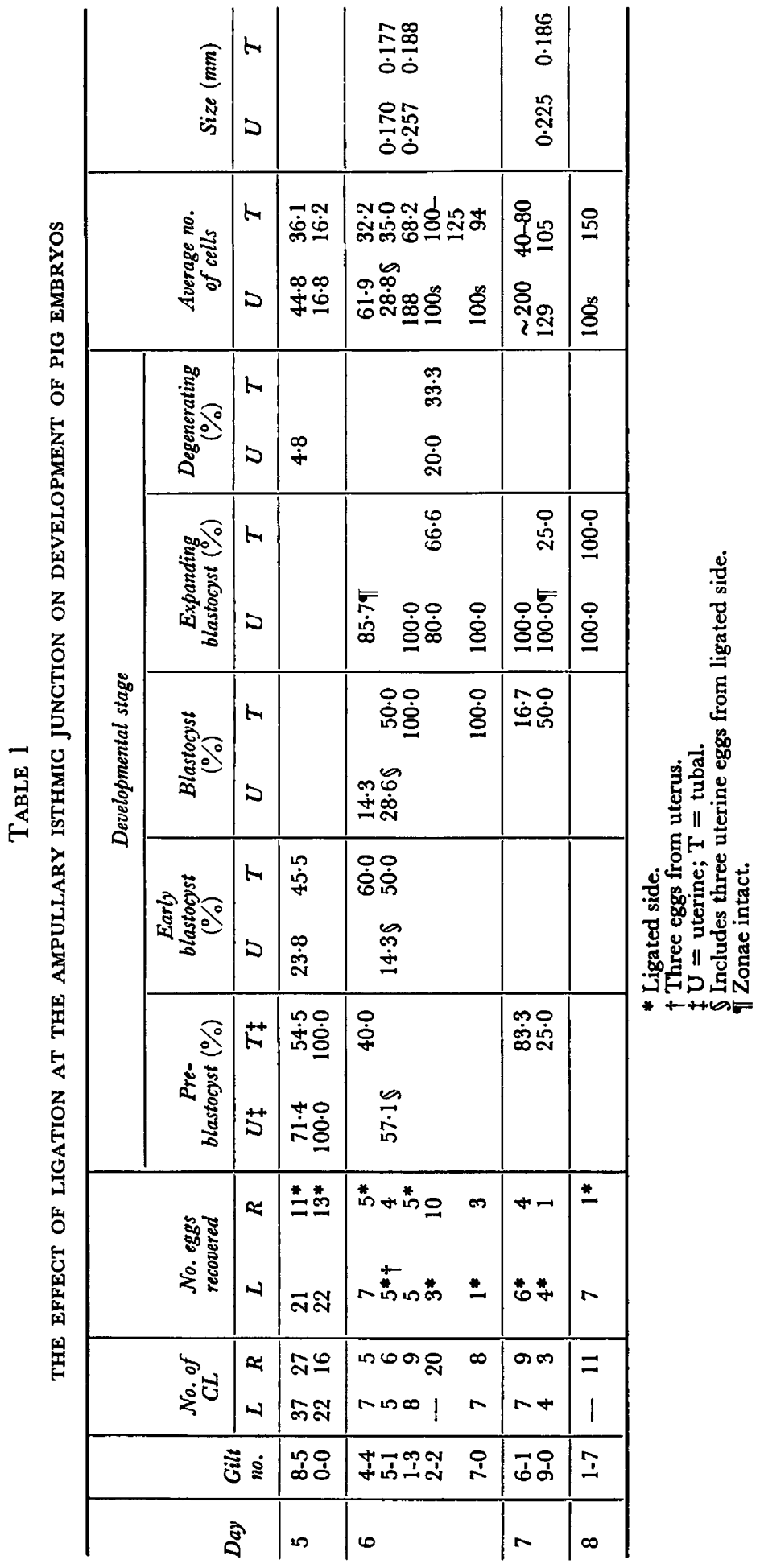


Orsini \& McLaren, 1967) and in vitro (Biggers, Gwatkin \& Brinster, 1962; Brinster \& Biggers, 1965; Whittingham, 1968). At present, there is no obvious explanation for the failure of embryos to develop to the blastocyst stage when cultured in the explanted isthmic portion of the mouse oviduct (Whittingham, 1968) or following restriction to the oviduct by placing a ligature at the uterotubal junction in the pig (Murray et al., 1971). The ampullar portion is the most active secretory region of the entire oviduct in the mouse (Reinius, 1967) and the ewe (Restall, 1966). Restall \& Wales (1968) found that secretion from the ampulla was double that from the isthmus in the ewe, but that the fluids obtained from each region were similar in composition.

\section{REFERENCES}

ADAms, C. E. (1958) Egg development in the rabbit: the influence of post-coital ligation of the uterine tube and of ovariectomy. 7. Endocr. 16, 283.

Alden, R. H. (1942) Aspects of the egg-ovary-oviduct relationship in the albino rat. II. Egg development within the oviduct. F. exp. Zool. 90, 171.

Biggers, J. D., Gwatkin, R. B. L. \& Brinster, R. L. (1962) Development of mouse embryos in organ cultures of Fallopian tubes on a chemically defined medium. Nature, Lond. 194, 747.

Billington, W. D., Graham, G. F. \& McLaren, A. (1968) Extra-uterine development of mouse blastocysts cultured in vitro from early cleavage stages. 7. Embryol. exp. Morph. 20, 391.

Brinster, R. L. (1963) A method for in vitro cultivation of mouse ova from two-cell to blastocyst. Expl Cell Res. 32, 205.

Brinster, R. L. \& BigGers, J. D. (1965) In vitro fertilization of mouse ova within the explanted Fallopian tube. J. Reprod. Fert. 10, 277.

Folstad, L., Bennett, J. P. \& Dorfman, R. I. (1969) The in vitro culture of rat ova. 7. Reprod. Fert. $18,145$.

KANE, M. T. \& Foote, R. H. (1970) Culture of two- and four-cell rabbit embryos to the expanding blastocyst stage in synthetic media. Proc. Soc. exp. Biol. Med. 133, 921.

KIRBY, D. R. S. (1962) The influence of the uterine environment on the development of mouse eggs. 7. Embryol. exp. Morph. 10, 496.

KRISHNAN, R. S. \& DANIEL, J. C., JR (1967) "Blastokinin": inducer and regulator of blastocyst development in the rabbit uterus. Science, $\mathcal{N} . Y .158,490$.

Murray, R. A., Jr, Bazer, F. W., Rundell, J. W., Vincent, C. K., Wallace, H. D. \& Warnick, A. C. (1971) Developmental failure of swine embryos restricted to the oviducal environment. F. Reprod. Fert. 24, 445.

Orsini, M. W. \& McLaren, A. (1967) Loss of the zona pellucida in mice, and the effect of tubal ligation and ovariectomy. F. Reprod. Fert. 13, 485.

ReInius, S. (1967) Ultrastructure of epithelium in mouse oviduct during egg transport. Proc. Vth Wld Congr. Fert. Steril., Excerpta Med. Int. Congr. Ser. 133, 199.

Restall, B. J. (1966) Histological observations on the reproductive tract of the ewe. Aust. F. biol. Sci. 19, 673.

Restall, R. J. \& Wales, R. G. (1968) The Fallopian tube of the sheep. V. Secretions from the ampulla and isthmus. Aust. F. biol. Sci. 21, 491.

Whitten, W. K. (1956) Culture of tubal mouse ova. Nature, Lond. 177, 96.

WhITTEN, W. K. \& BIGGERs, J. D. (1968) Complete development in vitro of the pre-implantation stages of the mouse in a simple chemically defined medium. J. Reprod. Fert. 17, 399.

WhitTingham, D. G. (1968) Development of zygotes in cultured mouse oviducts. I. The effect of varying oviductal conditions. $\mathcal{F}$. exp. Zool. 169, 391. 